\title{
Conceptualizing Language Learning Metaphors in the Saudi EFL Context: Practicality, Applicability \& Appropriacy
}

\author{
Mansoor S. Almalki* \\ English Language Centre, Deanship of Supportive Studies, Taif University, Taif 21974, Saudi Arabia
}

Corresponding Author: Mansoor S. Almalki, E-mail: msamalki@tu.edu.sa

\section{ARTICLE INFO}

\section{Article history}

Received: June 04, 2017

Accepted: August 26, 2017

Published: December 01, 2017

Volume: 6 Issue: 7

Special Issue on Language \& Literature Advance access: September 2017

Conflicts of interest: None Funding: None

\begin{abstract}
This paper tries to investigate the trends about the use of metaphors in the Saudi EFL classrooms. The proper implementation of metaphors (i.e. instruction, acquisition, and socialization metaphors) by teachers can be a reason for boosting source in the interactional and instructional patterns of the Saudi EFL classrooms, and the significance of these metaphors at aforementioned settings was investigated in the present study. Focusing upon the perceptive design of the study, a survey was conducted to know the significance of the three metaphors in the interactional settings of the Saudi EFL classrooms. This study targeted Saudi EFL teachers' attitudes towards the three delimited metaphors. The respondents consisted of 200 Saudi EFL teachers drawn from the English Language Centers of the Saudi Universities. A 22-item Likert-scale questionnaire was designed to know the opinions of Saudi EFL teachers about the dynamic use of metaphors in the context of the Saudi EFL classroom. The findings of the study reflected that the Saudi EFL teachers represented by the cohort of this study presented a mixed attitudes towards the utilization of the three delimited metaphors. The findings show that a limited exposure of instructional metaphor may be one of the reasons of the poor performance of the Saudi EFL teachers. A limited exposure of acquisition metaphor may also be damaging the dynamics of teacher student interactional and instructional patterns inside the Saudi EFL classrooms. The findings further show that the teachers' imbalanced use of class time and hardly any reliance on the coordinated interaction might be due to the limited exposure to the latest techniques embedded in the socialization metaphor. Although policy makers do not acknowledge the fundamental role of metaphors into classroom pedagogies, the participant-teachers recommended professional use of all the metaphors to achieve prerequisite dynamics of the EFL classrooms by fully acknowledging the applicability, appropriateness, and practicality of all the variables of acquisition metaphor.
\end{abstract}

Keywords: Metaphor Awareness, Saudi EFL Teachers, Instruction Metaphor, Acquisition Metaphor, Socialization Metaphor, Metaphoric Processing

\section{INTRODUCTION}

The significance of metaphor in language teaching and learning has been examined in second/foreign language learning. The application of metaphor in language teaching began approximately thirty years ago and it is situated in the cognitive linguistics paradigm (Danesi, 1986). The utilization of literature that investigates the relationship between metaphor and language learning has increased extensively, with most studies revolving around the conceptual role of metaphors. Lakoff and Johnson (1980) forwarded the Conceptual Metaphor Theory and asserted that metaphor is a matter of the mind, not an issue of language. According to Lakoff and Johnson (1980, p. 5) " the essence of metaphor is understanding and experiencing one kind of thing in terms of another". Lakoff and Johnson's theory offered a theoretical framework to study metaphorical language and thoughts in all the disciplines (Gibbs, 2008). Lakoff and Johnson delineate (1980, p. 9) that

"In all aspects of life, we define our reality in terms of metaphors and then proceed to act on the basis of the metaphors. We draw inferences, set goals, make commitments, and execute plans, all on the basis of how we in part structure our experience, consciously and unconsciously, by means of metaphor"

A great number of linguists and researchers in the discipline of language and linguistics are becoming interested in the metaphor, and anomalously powerful claims have been made about the influence of metaphor in almost every aspect of language education. The use of the three metaphors of language learning as instruction, language learning as acquisition, and language learning as socialization represents a shift in ideology concerning the nature of language learning. Nonetheless, certain approaches to teaching and learning 
of languages are more common in certain settings (Khan, 2011). In Saudi Arabia, research has been done on the second language learning environment, particularly in relation to the teaching and learning of the English language (Khan, 2011). Saudi Arabia uses a formal lecture-based approach to teaching and learning, similar to the 'instruction' metaphor (Almalki, 2011; Alebaikan, 2010). The literature on language learning in Saudi Arabia argues that language learning as an instruction predominates the educational landscape (Elyas \& Picard, 2010).

Concerning pedagogical success in Saudi Arabian language learning, achievement is increasingly demonstrated through meeting the requirements of internationally standardized tests that assess the global proficiencies of speaking, listening, reading, and writing (Khan, 2011). Having said this, achieving native-like production of language which is error-free is believed to be the ideal demonstration of achievement in language learning (Khan, 2011). With the development of EFL practices today, there will be a shift in language learning. This shift will be in moving from language learning as 'Instruction', as it is currently, to language learning as 'Socialization', where learning focus can be more on multimodal activities and the overall growth of the language community.

A large body of research acknowledges the power and significance of metaphor in the pedagogy of teaching English as a second or foreign Language (Boers, 2000; Lazar, 1996; Littlemore, 2004). The use of metaphor as an pedagogical tool in teaching lanugae is not quite new, however, the utilization of it has been limited and narrow. Most of the inquiries in this area focus only on the potential of metaphor in increasing vocabulary retention (Boers, 2000; Lazar, 1996; Littlemore, 2004). It's a reason that application of metaphor as a teaching tool has taken a long time to "make significant headway into mainstream pedagogical practice and the design of teaching materials" (Littlemore and Low, 2006, p. 4). Despite clear and solid theoretical implications, not much attention and due importance has been given to the empathic potential of metaphor as a teaching methodology. In order to widen the scope of metaphor in language teaching, the current studyexamines the current scenario on the role of metaphors in language teaching and learning, and also examines how metaphoric processing was understood by the Saudi EFL interactants. It is prudent to consider the value of metaphor in language research and pedagogical contexts. And this is a shift that is already beginning to happen as explained in the next section.

\section{LITERATURE REVIEW}

\section{Language Learning as 'Instruction'}

Language learning as instruction focuses on the traditional notion of the student as a recipient of knowledge and skills, as well as on a didactic role of the instructor as controller of information (Richards \& Rodgers, 2001). Predominating language 'teaching' for a century until the $1950 \mathrm{~s}$, the grammar-translation method of language learning comprised the direct translation of the target language into the student's pri- mary language. Lessons focused mainly on teaching reading and writing skills with fixed or ultimate correct answers. Thus, every student was expected to provide the same convergent answer (Low, 2003). The grammar-translation method placed emphasis on reading and writing, and demanded of students that they must demonstrate the translation of a passage of the target language into their first language (Gozdawa-Gołębiowski, 2013). Based on the grammar-translation method, language course plans focused on the accuracy of the translation and fluency of the communicated translation (Gozdawa-Gołębiowski, 2013). According to (Low, 2003), thus, accuracy and fluency were strong themes in learning items, such as in accurately translating a paragraph of writing from Arabic to English, for example. In this era, the emphasis in learning was to achieve the correct linguistic product, rather than to develop cognitive strategies or social process. Students were imitators, instructors used error correction to force accuracy, and researchers reduced linguistics to structural analysis of minute detail. The curriculum design was a fixed set of grammar and vocabulary. The dominant pedagogy was instruction and success was defined as native-like fluency and accuracy in the new language. With the grammar-translation method primarily being concerned with reading and writing, features of the language, such as accurate spelling and correct word choice were the focus of learning: they were the learning units that were the outcomes that the student was able to achieve in the target language (Richards \& Rodgers, 2001). The choice of the metaphor 'instruction' for this type of language learning is most likely to be derived from the focus on a direct instructor to student approach in the instruction of language (Low, 2003). Despite different innovative tools being used by educators around the world today, the instruction metaphor of language learning is still used in many EFL settings (Low, 2003). Among the issues for an instruction-based approach to language learning is that the focus on the educator can foster a dependency in students on the educator as the sole source of information.

\section{Changes in Language Learning - Learning by 'Acquisition'}

By the 1970s, the audio-lingual method, focussing on structure, emerged as a useful approach to second language learning (Richards \& Rodgers, 2001). Advocates of the audio-lingual method argue that there were many repeating structures within language that could be learned (Richards \& Rodgers, 2001). Researchers in second language learning found that the audio-lingual method emphasised exposure to the structures of the language, rather than using translation, so that the target language could be acquired through recitation and other methods (Chappelle, 2004; Ellis, 1997). The shift to a focus on 'acquisition' in learning a second language meant that pedagogical goals were aligned to assessing whether the student had acquired the skill of using the present perfect tense (that is, the target structures of language) while previous learning was concerned with speaking and listening. Learning objectives now relates to performing and interacting in the target language. Achievement in a particular learning course is therefore defined differently in the grammar-transla- 
tion method; the latter requiring native speaker accuracy and fluency and being excessively concerned with details (Low, 2003). Richards and Rodgers (2001) maintain that the change in the language pedagogy was towards multi-dimensional learning objectives where learning and teaching included speaking, listening, reading and writing. Pedagogical success in language learning was demonstrated by proficiency in these four areas, or global proficiencies (Ellis, 2003). Many settings, even today, are still believed to adhere to language teaching practices which are consistent with the acquisition approach (Gruba\&Hinkelman, 2012), and the rise of the acquisition world view of language learning can still be seen today in the case of high stakes tests. Global tests of English such as the International English Language Testing System (IELTS) and the Test of English for International Communication (TOEIC) have been derived from the acquisition model (Gruba\&Hinkelman, 2012).

\section{The 'Socialization' Metaphor}

Knight, Studdert-Kennedy, and Hurford (2000) argues against the biological interpretation of language acquisition, citing social evolution and the influence of culture and history in creating an evolving language. As well as, immersion in the target language has been encouraged by the advent of Web 2.0 (the 'social web' which facilitates interactive sharing) (Gray et al., 2011). Along the same lines as this socialization theme, Skehan (1998) argues that students need to actively use the target language to be competent: developing skills in the language, becoming articulate, and the need for interaction countered the idea that mere exposure is sufficient to learn a language. This approach is known as socialization, which is now a popular approach to learning a second language (Davis, 2012).

Language learning using socialization is linked to the increased social skill development in students (Netten \&Germain, 2010), deeper learning (Larsen-Freeman, 2000), rapid uptake of symbols, improved academic results (Duff, 2010) The socialization metaphor emphasises the role of substantive communication. While earlier perspectives placed greater distance between language student and language teacher, philosophers started to note that students of foreign languages benefited from immersion in the target language, and in particular from opportunities to socialize using their new language (Davis, 2012; Duff, 2010; Hill \& McNamara 2012; Netten\&Germain, 2010). Learning in this format involves weighting of the learning components, especially substantive communication that involves using language for meaning and in real situations.

Larsen-Freeman (2000) and Dinçay (2010) provide examples of typical learning activities used within the socialization approach. These activities include:

1. Authentic materials. Students may not be able to directly use their knowledge outside the class. To overcome this, everyday items in the target language can be used, including newspaper articles, weather forecast charts, timetables, and menus.

2. Scrambled sentences and other language games. Games are frequently used in Communicative Language Teach- ing (CLT), alongside role playing and interviews and other interactions between the students, for the purposes of flexibility and broadening the curriculum.

3. Comic strips. These are used because the pictures give indications of the text.

The above activities promote confidence and allow self-expression. In summary, the contemporary second-language goal in modern times, as expressed by the socialization metaphor, is demonstrating accomplishment in using the language in real situations.

\section{Objectives}

Most research studies investigated the three language learning metaphors in settings like ESL, and there is a lack of research by investigating these metaphors in the EFL setting and especially in the Saudi EFL context. Therefore, it is assumed that the current research study will help contribute in shedding light on the best EFL teaching practices by investigating teachers' perceptions about the three language learning metaphors and so help in determining which one of these is more appropriate, practical and applicable in such settings. Thus, the objectives of this study are;

1. To investigate EFL language teachers' perceptions about the three language learning metaphors (i.e. instruction metaphor, acquisition metaphor, and socialization metaphor) in the Saudi EFL context.

2. To determine the practicality and applicability of the metaphors in the Saudi EFL classrooms.

3. To identify the appropriateness of language learning metaphor in the context of Saudi EFL classrooms.

\section{Research Questions}

Based on the research objectives mentioned above, I propose the following four research questions;

1. How do language teachers perceive the instruction metaphor of language learning in the EFL context?

2. How do language teachers perceive the acquisition metaphor of language learning in the EFL context?

3. How do language teachers perceive the socialization metaphor of language learning in the EFL context?

4. What is the most appropriate language learning metaphor in the Saudi EFL context?

\section{RESEARCH METHODOLOGY}

Quantitative approach was considered as a necessary design for the present study to provide precise measurement of the respondents' views to reach a systematic conclusion. In this kind of research, results are more readily analyzed, interpreted in the terms of numbers with an objective to achieve precision (Strauss and Corbin, 1990). In the present work, a quantitative research method was selected to investigate the phenomena under study. The cross sectional survey was used as a tool to gather information from a pre-designed questionnaire. The respondents of this study were $200 \mathrm{EFL}$ teachers, both male and female working at the Language Centre of the Saudi Universities. In this study, simple ran- 
dom sampling techniques were used to select respondents as a sample. Bell (1999, p. 126) opines that "a random sample will give each of the individuals concerned an equal chance of being selected." Further, a different sections of the questionnaire were designed in order to check the appropriateness of the survey items, the thing that enabled a researcher to elicit respondents' authentic responses and examine the appropriateness, practicality and applicability of the three language learning metaphors. Consequently, 24-item Likert-scale questionnaire tried to focus on the domains of instruction, acquisition, socialization, appropriateness, practicality and applicability. In addition, a pilot study was also administered to examine the suitability of the survey. The English version of the online questionnaire was distributed to the respondents. Finally, I gathered data on the basis of a structured questionnaire and drew the conclusions from the findings accordingly.

\section{Delimitations of the Study}

This study was delimited to explore and analyze the significance of three metaphors in the context of the Saudi EFL classrooms. The focus of the study was narrowed down to the important functions of three metaphors such as instruction metaphor, acquisition metaphor, and socialization metaphor only. The present study did not include the use of metaphors as a metacognitive research tool to explore the conceptions of learning and teaching. Conversely, it focused only on studies that examined metaphor as a pedagogical entity.

\section{Instrumentation}

From the very outset of the study, I carefully considered selecting reliable methods that would help to identify the research problems. Thus, in order to investigate the phenomena under study, I used a survey as a research instrument as it allows asking a large group of people questions related to the issue of interest (Fraenkela, \& Wallen, 2000:432). The reliability and validity of the questionnaires were determined by the pilot project and, consequently, well planned and structured questionnaire was used to get a reliable data. For this purpose, English version of the questionnaire was provided to the subjects.

\section{Statistical Analysis}

At the stage of analysis, the responses of the subjects were analyzed to determine the significance of different variables of metaphors in the Saudi EFL classrooms. The significance was determined by applying the value of mean for all the variables, but the significance of each variable of metaphors was determined by the value of the mean while considering its importance in the language research. As Brown (1988:154) defines: "the central tendency of groups is often described in terms of means and medians. Comparing the performance of groups will often involve looking at one or both of these basic characteristics". Finally, the results were demonstrated by using frequency distribution tables.

\section{RESULTS AND DISCUSSION ON THE FIRST PART OF THE QUESTIONNAIRE}

The data generated through the questionnaire was analysed to examine the research questions. The questionnaire of the present survey was administered to the teachers (both males and females) to identify the significance of all three metaphors in the Saudi EFL classrooms. The following Table 1 ranked hierarchy as determined by the respondents, and also presented individually identified mean scores for all the variables of the questionnaire.

Based on the mean scores taken from the section of instruction metaphor, the five items displayed the respondents' ranking of variables from the most significant to the least significant. The most important item as identified by the respondents was item two 'I talk more than my students in the classroom' with a mean of 3.04. Hence, results report that the item two of the instruction metaphor revealed a big gap between teacher and student interactions. Therefore, such responses imply that there is a dire need to enhance the instructional patterns to achieve true objectives of the language learning through exposing instruction metaphor in the Saudi EFL classrooms.

The first item was the second most important item 'instructing my students is the only approach I use' with a mean of 2.49. The preference of the respondents reflected that there was an urgent need to revisit the dynamics related to the instruction metaphor. Moreover, the present study revealed that the teachers relied more on teachers' talk to control the classroom instructional and interactional patterns and it implies that they were not fully acquainted with the classroom talk patterns. Also, it was an important finding that reflected the major drawback about the prerequisite of the Saudi EFL classrooms. Thus, the present study may imply a significant finding that the teachers were not fully aware of the implications of instruction metaphor, and it implies that Saudi EFL classrooms were deprived of standardized classroom dynamics such as talk time, interaction patterns, and instructional designs. This significant finding coincides with the beliefs of Boers (2000) who also delineates metaphor awareness as the ability to recognize the ubiquity, underlying themes, non-arbitrary nature, cross-cultural differences and cross-linguistic variety in the linguistic instantiations of metaphorical expressions. Gulzar and AlAsmari (2014) who argued that students also needed an exposure to a rich variety of classroom dynamics, and such exposure could contribute to general language improvement as well as fostering a general competence. The fourth variable 'external materials are not appropriate in my class' with a mean of 2.20 was ranked third by the respondents. Data analysis showed that item five 'I don't spend time talking to my students about their learning interests' with a mean of 2.18 was the least preferred variable by the respondents. Clearly, the teachers' responses confirmed that instruction metaphor was difficult for the teachers to understand and apply in the EFL classrooms. Presenting this reason as a case, it can be confirmed that teachers could not reflect a proper understanding to achieve the required skills for classroom dynamics by applying three metaphors. This finding seems to suggest that pure traditional teaching meth- 
ods of teaching are employed in the Saudi EFL classrooms and that may be one of the reasons for the low preference of this variable. In the Saudi EFL classrooms, teachers were not properly trained to know the prerequisite of classroom dynamics, e.g. how to stipulate class time span, turn taking and interactional patterns according to the pre-requisites of the instruction metaphor. It is rightly pointed out by Kalyuga and Kalyuga (2008) who suggested raising metaphor awareness by enhancing metaphoric awareness via activities that help participants to establish the associations with the metaphorical expressions and its more comprehensive utilization can lead to higher retention rate of contents (Boers, 2000; Guo, 2007). Discussing and comparing metaphors in the first and target language can also be effective in improving learners' metaphor comprehension and production (Deignan, Gabrýs, \& Solska, 1997). The findings of the current study agree with(Low, 2003) that despite different innovative tools being used by educators around the world today, the instruction metaphor of language learning is still used in many EFL settings including in the EFL context of Saudi Arabia.

\section{RESULTS AND DISCUSSION ON THE SECOND PART OF THE QUESTIONNAIRE}

The following Table 3 presented the analysis of the results of part 2 of the questionnaire along with ranked hierarchy through individually identified means as recognized by the respondents for all the variables.

In Table 2, item 3 'my students need to be able to use situational English (i.e., using the language in particular real life situations) effectively' was shown to be the most preferred variable to teach English getting support from the materials based on a real life like situation with a mean of 4.25 .
It was an important finding that considering the importance of situational English teachers recommended the use of all four language skills in the Saudi EFL classrooms. However, that was specified with acclimatizing them to the situational use of English to facilitate students to overcome their deficiencies. This result aligns with the suggestion as given by Savignon, (1986, p. 145) who stated that "items from newspapers, popular, or professional magazines can be introduced over a period of time for intensive and extensive exposure of English language". And it is true because sometimes even a single page of a newspaper provides a plenty of the exposure of situational English in the classroom. This way, teachers may take out students from the cycle of dissatisfaction created due to redundant lesson plans based on the artificially designed materials, and hence they can lead students towards the cycle of improvement by devising lesson plans based on such situational materials. Tuckner explaining the same situation (1986) claims that educational changes cannot be rushed, attitudinal change in Homo sapiens may be a long, painful or frustrating process, but it does happen. Item five 'it is important to give my students' assignments on the four language skills (e.g., listening, speaking, reading, writing)' with a mean of 3.86 was reported as the second most preferred variable. Similarly, AlAsmari \& Gulzar (2016) also claim that situational material may provide their students with realistic experiences which capture their attention and appeal to the mind through visual auditory senses. Thus, this kind of material may be used as good teaching tools because they can provide many benefits and can also keep students' interest and motivation intact. Data analysis also showed that the third most preferred item was one 'I always focus on teaching the four skills of English (e.g., listening, speaking, reading, writing)' scoring a mean of 3.80. and it was

Table 1. Saudi EFL Teachers' Beliefs about using instruction metaphor for language teaching. Analysis of Teachers' questionnaire

\begin{tabular}{lcc}
\hline Teachers' beliefs about using instruction metaphor for language teaching & Rank & Mean \\
\hline 1. Instructing my students is the only approach I use & 2 & 2.49 \\
2. I talk more than my students in the classroom & 5 & 3.04 \\
3. Students don't need to interact with each other in my classroom & 3 & 1.76 \\
4. External materials are not appropriate in my class & 4 & 2.20 \\
5. I don't spend time talking to my students about their learning interests & 4.18 \\
\hline
\end{tabular}

Table 2. Saudi EFL Teachers' Credence about the effectiveness of acquisition metaphor for language teaching

\begin{tabular}{|c|c|c|}
\hline EFL Teachers' Credence about the effectiveness of acquisition metaphor for language teaching & Rank & Mean \\
\hline $\begin{array}{l}\text { 1. I always focus on teaching the four skills of English } \\
\text { (e.g. listening, speaking, reading, and writing) }\end{array}$ & 3 & 3.80 \\
\hline $\begin{array}{l}\text { 2. My students need to be competent in each of the four skills } \\
\text { (e.g. listening, speaking, reading, and writing) to consider them eligible to pass my exams }\end{array}$ & 4 & 3.56 \\
\hline $\begin{array}{l}\text { 3. My students need to be able to use situational English } \\
\text { (i.e. using the language in particular real life situations effectively) }\end{array}$ & 1 & 4.25 \\
\hline $\begin{array}{l}\text { 4. I divide my lesson plans equally on the four language skills } \\
\text { (e.g. listening, speaking, reading, and writing) }\end{array}$ & 5 & 3.34 \\
\hline $\begin{array}{l}\text { 5. It is important to give my students' assignments on the four } \\
\text { language skills (e.g. listening, speaking, reading, and writing) }\end{array}$ & 2 & 3.86 \\
\hline
\end{tabular}


Table 3. Saudi EFL teachers' perceptions about teaching language as a socialization metaphor

\begin{tabular}{lcc}
\hline Saudi EFL teachers' perceptions about teaching language as socialization metaphor & Rank & Mean \\
\hline 1. I always spend most of my class time talking to my students about their hobbies and life interests & 4.69 \\
2. My students are always encouraged to interact with each other using English & 2 & 3.85 \\
3. I always use external authentic materials to help my students understand more about the culture & 3 & 3.79 \\
and use the language effectively & 1 \\
4. It is important to involve all students in different class activities & 4.26 \\
\hline
\end{tabular}

graded at number three by the respondents. Metaphor awareness-raising activities help language learners in the reading of literature both in immediate and delayed interpretation, as shown in Picken $(2005 ;$ 2007). Moreover, explaining these activities, Sacristán, (2009) defines these activities, when incorporated in translation classes, can enhance cross-linguistic awareness, translation competence, metaphoric competence, learner autonomy, interactive learning and critical thinking. In Csábi's study (2004), learners who were exposed to metaphor-awareness instruction outperformed their peers in comprehension. The results of this variable reflected that the teachers were using all four language skills in the Saudi EFL classrooms. Based on that, it might be implied that the teachers' were fully exposed to an acquisition metaphor to a greater extent. Item two 'My students need to be competent in each of the four skills (e.g. listening, speaking, reading, writing) to consider them eligible to pass my exams.' with a mean of 3.56, and item four 'I divide my lesson plans equally on the four language skills (e.g., listening, speaking, reading, writing)' scoring a mean of 3.34, were both respectively ranked at fourth and fifth positions by the respondents in the priority list of the variables. The inclination of the Saudi EFL teachers revealed that that the teachers were not only acquainted, but also practicing, teaching following the dynamics of the acquisition metaphor. Adding to the point, based on the results provided in Table 2, that lesson plans can be devised keeping in view all the language skills but measuring the level of the students. The beliefs of the teachers as emerging while sequencing the findings coincide with the beliefs reported by Crystal's (2000), and Dubin and Olshtain (1981). Thus, the present study findings put across that teachers were fully responsive about the induction of all the language skills and situational sequences to enhance the competence of the Saudi EFL students which advocate the findings by (Gruba\&Hinkelman, 2012) that many settings, even today, are still believed to adhere to language teaching practices which are consistent with the acquisition approach

In Table 3, item four 'it is important to involve all students in different class activities' was identified as the most preferred variable as supporting group work and pair work with a mean of 4.26. It was an imperative finding that considering the importance of socialization metaphor, teachers were found inclined interacting with students using English and use of authentic material to present a real life like situation. However, that was conditioned to teach language as a socialization metaphor to enable students to encounter day to day life situations. This result may align with the suggestion of Savignon, (1986) who stated that sometimes a few extracts from the newspaper can break the monotonous en- vironment in the classroom. This way, teachers may manage to take out students from the cycle of frustration created due to redundant lesson plans based on the official books, and hence they can lead them towards the cycle of development by devising lesson plans according to the prerequisite of the socialization of metaphors (Gulzar \& AlAsmari, 2014). Tuckner explaining the same/or opposite situation (1986) claims that Awareness-raising activities are generally found to be more effective than rote learning activities. Such activities are effective because they call learners' attention to the metaphoric nature of language (Gibbs, 1994; Lakoff \& Johnson, 1980). Item two 'my students are always encouraged to interact with each other using English' with a mean of 3.85 was reported as the second most preferred variable. Jin's (2011) analysis of spatial metaphors in Chinese students' writings and Littlemore et al.'s (2014) investigation of metaphors in German and Greek students' essays also displayed a developmental trend in metaphor used across proficiency levels. Therefore, the use of English in the Saudi EFL classroom discourse can provide an environment in which students can practice listening and speaking skills in the classroom. The respondents of the study ranked item three, 'I always use external authentic materials to help my students understand more about the culture and use the language effectively' at third position with a mean of 3.79. Data analysis also showed that the least preferred item was one 'I always spend most of my class time talking to my students about their hobbies and life interests' scoring a mean of 2.69 which was graded at number four by the respondents. Based on the reflected results, it might be implied that the teachers' imbalanced use of class time and hardly any reliance on the coordinated interaction might be due to the limited exposure to the latest techniques embedded in the socialization metaphor. For example, a learner's L1 knowledge and culture may influence metaphoric processing in the L2, however, in terms of L2 learners' metaphoric processing, L1 knowledge seems to be the useful strategy (Azuma, 2009; Cooper, 1999). And teaching trends can be improved if the teaching language is based on social metaphors. Because, language learning using socialization is linked to the increased social skill development in students (Netten\&Germain, 2010), deeper learning (Larsen-Freeman, 2000), rapid uptake of symbols, improved academic results (Duff, 2010). The beliefs of the teachers as emerging while sequencing the findings coincide with the beliefs reported in Azuma, (2009) and Cooper (1999). Thus, the findings of the present study revealed that teachers were aware about the significance of items two and four, but they were not confident about the use of items 
three and one as an aid to enhance English language competence of the Saudi PYP students.

In Table 4, a comparative analysis of all three metaphors was presented to reflect the teachers' determined applicability, appropriateness, and practicality among all three metaphors about the Saudi EFL classrooms. In Table 4, items one to three present applicability, appropriation, and applicability for the instruction metaphor. Similarly, items four to to six present applicability, appropriateness, and practicality for the acquisition metaphor. Likewise, items seven to nine reflect applicability, appropriateness, and practicality for the instruction metaphor. The most important metaphor as reflected by the respondents was acquisition metaphor. Items four, five and six were ranked respectively at the positions of one, two and three. It reflected that the EFL Saudi teachers fully acknowledged the applicability, appropriateness, and practicality of all the variables of acquisition metaphor. The findings of the respondents reflected that they were applying all these techniques in the EFL classrooms. The research that promotes the utilization of metaphors in the EFL classrooms assumes that the metaphors can enhance the process of language learning among the students. Due to the use of metaphors, learners draw attention to the metaphoric process of language, and can also facilitate the comprehension process. Yasuda's (2010) experiment with Japanese students on phrasal verbs forwarded similar findings. Li (2009) also found that the intended application of metaphors in a series of experiments with 394 Chinese learners of English led to higher scores in recall post-tests in the experimental group (e.g., Li, 2009; Yasuda, 2010). Azuma (2009) also elaborates the significance of metaphor by acknowledging the recognition of metaphorical expressions in receiving discourse, use of metaphorical expressions in producing discourse and understanding of the underlying concepts of metaphors in both L1 and L2. The results of the present study also reflect the moderately same results as mentioned in the above studies, e.g. the second most important metaphor was socialization metaphor as indicated by the respondents of the study. Item seven was ranked at fourth position and item eight was identified at number six position and similarly respondents ranked item nine at the eighth position. In this metaphor, respondents could not trace-out the applicability of variable nine and they ranked it at number eight to show very low applicability of this variable. It was very significant finding as it indicated that teachers were not applying interactional techniques related to applicability. Thus, in the metaphor of socialization, respondents did not fully authenticate the applicability, appropriateness, and practicality of the socialization metaphor. The third significant metaphor was an instruction metaphor as determined by the respondents of the present study. The first item was ranked at ninth position and item two were identified at number seven position and respondents identified item three at the fifth position. In this metaphor, respondents could not determine the great significance for all the variables clustered in the instruction metaphor. Likewise the applicability of variable nine of socialization metaphor and they ranked at number eight to show very low significance of this variable. It requires too much contribution on the part of the teachers to be viable: Paying attention to the learner's individual aptitudes and provide them training that can help them apply autonomously the needed knowledge to the right task. It was a pivotal finding reflected a critical issue about the teachers' failure to properly conceive the interactional and instructional patterns

Table 4. Saudi EFL teachers' appropriateness, practicality and applicability of the above mentioned three metaphors

\begin{tabular}{|c|c|c|}
\hline Appropriateness, practicality and applicability of instruction metaphor & Rank & Mean \\
\hline $\begin{array}{l}\text { 1. I see the instruction metaphor of language learning } \\
\text { (i.e., more teacher-to-student teaching than student-to-student learning) as the most appropriate (i.e., will be } \\
\text { helpful if implemented) in my classroom }\end{array}$ & 9 & 3.17 \\
\hline $\begin{array}{l}\text { 2. I see the instruction metaphor of language learning (i.e., more teacher-to-student teaching than } \\
\text { student-to-student learning) as the most practical (i.e., works effectively with students) in my classroom }\end{array}$ & 7 & 3.39 \\
\hline $\begin{array}{l}\text { 3. I see the instruction metaphor of language learning (i.e., more teacher-to-student teaching than } \\
\text { student-to-student learning) as the most applicable (i.e., can easily be implemented) in my classroom }\end{array}$ & 5 & 3.51 \\
\hline Appropriateness, practicality and applicability of acquisition metaphor & Rank & Mean \\
\hline $\begin{array}{l}\text { 4. I see the acquisition metaphor of language learning (i.e., focusing on language skills) as the most } \\
\text { appropriate (i.e., will be helpful if implemented) in my classroom }\end{array}$ & 1 & 3.90 \\
\hline $\begin{array}{l}\text { 5. I see the acquisition metaphor of language learning (i.e., focusing on language skills) as the most } \\
\text { practical (i.e., works effectively with students) in my classroom }\end{array}$ & 2 & 3.76 \\
\hline $\begin{array}{l}\text { 6. I see the acquisition metaphor of language learning (i.e., focusing on language skills) as the most } \\
\text { applicable (i.e., can easily be implemented) in my classroom }\end{array}$ & 3 & 3.66 \\
\hline Appropriateness, practicality and applicability of socialization metaphor & Rank & Mean \\
\hline $\begin{array}{l}\text { 7. I see the socialization metaphor of language learning (i.e., less teacher-to-student teaching and more } \\
\text { student-to-student learning) as the most appropriate (i.e., will be helpful if implemented) in my classroom }\end{array}$ & 4 & 3.58 \\
\hline $\begin{array}{l}\text { 8. I see the socialization metaphor of language learning (i.e., less teacher-to-student teaching and more } \\
\text { student-to-student learning) as the most practical (i.e., works effectively with students) in my classroom }\end{array}$ & 6 & 3.46 \\
\hline $\begin{array}{l}\text { 9. I see the socialization metaphor of language learning (i.e., less teacher-to-student teaching and more } \\
\text { student-to-student learning) as the most applicable (i.e., can easily be implemented) in my classroom }\end{array}$ & 8 & 3.27 \\
\hline
\end{tabular}


between teachers and students. Consequently, the improper utilization of these patterns might be the reason of of the Saudi EFL students' poor performance in the context of the Saudi EFL classrooms. Thus, it can be claimed on the basis of the findings of the present study that the instruction metaphor is a dreary locale with the Saudi EFL teachers. Also, there is a dire need to understand the proper improvisation of all three metaphors to boost teaching and learning dynamics in the Saudi EFL classrooms.

\section{CONCLUSION}

The present study tried to investigate the implementations of three metaphors in the Saudi EFL classrooms at the university level. The present study findings confirmed the Saudi EFL teachers' awareness about the effectiveness of acquisition metaphor and socialization metaphor as an essential tool for improving the existing dynamics in the Saudi EFL classrooms. The findings of the study also identified that a limited exposure of instructional metaphor may be one of the reasons of the poor performance of the Saudi EFL teachers. Also, teachers were not fully exposed to acquisition metaphor and a limited exposure of acquisition metaphor may also damage the dynamics of teacher student interactional and instructional patterns inside the Saudi EFL classrooms. Based on the findings of the present study, it can be implied that complete awareness of all the metaphors can be very convenient tool to improve the classroom dynamics. Contrary to it, it is significant to highlight here that policy makers never acknowledged the fundamental role of metaphors into any policy related to classroom pedagogies. It can be said that this part despite carrying a great potential could not be recognized as a part of the classroom dynamics by our policy makers. The data based on the questionnaire provided useful insights of the Saudi EFL teachers' opinions towards the dynamic use of all the metaphors in the Saudi EFL classrooms. It can be concluded that the sample group clustered by the cohort of the sample in this study recommended more professional use of all the metaphors to achieve prerequisite dynamics of the EFL classrooms. Also, they asserted that wise use of all metaphors is essential for the Saudi EFL teachers to make pedagogical changes in the classroom dynamics to accomplish more academic benefits by applying different metaphors. Due to lack of awareness about the use of instruction metaphor, teachers and master trainer should devise lesson plans based on the fitting use of instruction metaphor to coordinate teacher-student interactional patterns. Moreover, it was quite alarming that teachers were indecisive about the utilization of some of the variables in the Saudi EFL classrooms and it may be one of the reasons of teachers' poor performance in the Saudi EFL classrooms. It can be concluded on the basis of the findings that the proper utilization of metaphors can help teachers to reset classroom dynamics, pedagogies and parameters to guarantee a harmonized academic atmosphere for all the Saudi students. A great number of researchers have made strong claims about the power of metaphor in almost every aspect of language education. Thus, it is significant to recognize the value of metaphor in language research and pedagogical contexts. The results of the study have also made this point clear that metaphors in the class act as as a factor affecting intimacy, and thus, effective and selective use of this intimacy can motivate students. Teacher's attitudes can create a greater influence on the students because the desirable indications of the metaphors express warmth, respect, fairness, and, conversely, the undesirable cues of the teachers communicate superiority, disinterest, and disrespect in the students. Consequently, the appropriate use of metaphors can influence students' moods, their perceptions, their learning and eventually can develop a perpetual effect on their learning capacities. Furthermore, teachers should be explicitly informed about the importance of different functions of these metaphors for teaching in the EFL classrooms. Henceforth, according to the findings of the study, metaphors appeared to be functional and valuable source for the teachers to perform different functions in the classroom of the Saudi EFL students. Thus, it can be claimed that the techniques which teachers constitute need to be critically analyzed to consider their effectiveness on students' learning in the Saudi EFL classroom.

\section{REFERENCES}

AlAsmari A.A. \& Gulzar, M.A. (2016). The Use of EFL Authentic Materials: A Gender-Line University Teachers' Perspective. International Journal of Applied Linguistics \& English Literature Vol. 5 No. 2; pp 128-136.

Alebaikan, R. A. (2010). Perceptions of blended learning in Saudi universities. PhD dissertation, University of Exeter.

Almalki, A. (2011). Blended learning in Higher Education in Saudi Arabia: A study of Umm Al-Qura University. $\mathrm{PhD}$ Thesis. RMIT University, Melbourne, Australia.

Azuma, M. (2009). Positive and negative effects of mother-tongue knowledge on the interpretation of figurative expressions. Papers in Linguistic Science, 15, 165-192.

Bell, J. (1999). Doing Your Research Project: A Guide for First-Time Researchers in Education and Social Science. Open University Press, Philadelphia, USA.

Boers, F. (2000). Enhancing metaphoric awareness in specialised reading. English for Specific Purposes, 19(2), 137-147.

Boers, F., Demecheleer, M., \& Eyckmans, J. (2004). Cross-cultural variation as a variable in comprehending and remembering figurative idioms. European Journal of English Studies, 8(3), 375-388.

Brown. (1999). Collaborative action research for English language teachers. U.K: Cambridge University Press.

Crystal, D. (2000). English as a Global Language. Cambridge University Press, UK.

Chapelle, C. (2004). Technology and second language learning: expanding methods and agendas. Systems. 32(4), 593-601.

Csábi, S. (2004). A cognitive linguistic view of polysemy in English and its implications for teaching. In M. Achard \& S. Niemeier (Eds.), Cognitive linguistics, second language acquisition and foreign language teaching (pp. 233-256). Berlin, New York: De Gruyter. 
Danesi, M. (1993). Metaphorical competence in second language acquisition and second language learning: The neglected dimension. In J. Alatis (Ed.), Language, communication, and social meaning (pp. 489-500). Washington: Georgetown University Press.

Davis, K. (2012). Ethnographic approaches to second language acquisition research. Encyclopesdia of Applied Linguistics. Hoboken, NJ: Wiley.

Deignan, A., Gabrýs, D., \& Solska, A. (1997). Teaching English metaphors using cross-linguistic awareness-raising activities. ELT Journal, 51(4), 352-360.

Dincay, T. (2010). A quick chronological review of the ELT methods along with their techniques and principles: choosing eclecticism from among language teaching methods. Language Magazine, (147), pp. 40-62. Accessed from dergiler.ankara.edu.tr/dergiler/27/1603/17283.pdf.

Dubin, F. and Olshtain, E. (1981). Reading By All Means. Addison-Wesley Publishing Company Inc., Phillipines, USA.

Duff, P. A. (2010). Language socialization into academic discourse communities. Annual review of applied linguistics, 30, 169-192.

Ellis, R. (1997). SLA Research and Language Teaching. Oxford University Press, 198 Madison Avenue, New York, NY 10016-4314.

Ellis,R.(2003).Task-based language learning and teaching. Oxford: Oxford University Press.

Elyas, T., \& Picard, M. (2010). Saudi Arabian educational history: Impacts on language teaching. Education, Business, Society: Contemporary Middle Eastern Issues, 3(2), 136-145.

Gibbs, R. W. (1994). The poetics of mind: Figurative thought, language, and understanding. Cambridge University Press.

Gozdawa-Gołębiowski, R. (2013). Basic dichotomies in foreign language teaching and learning: a case of formulaic language. In D. Gabryś-Barker, E. Piechurska-Kuciel, \& J. Zybert (Eds.) Second language learning and teaching, pp. 35-50. Cham, Switzerland: Springer

Gruba, P., \&Hinkelman, D. (2012).Blending technologies in second language classrooms. Basingstoke, England: Palgrave McMillan.

Gulzar, M.A. \& Abdulrahman A.A. (2014). Effects of Print Media: A Study of Reading Skills among University EFL Students. Research on Humanities and Social Sciences, Vol.4, No.28; pp 68-79, ISSN (Paper) 2224-5766 ISSN (Online) 2225-0484 (Online) www. iiste.org.

Guo, S. (2007). Is idiom comprehension influenced by metaphor awareness of the learners? A case study of Chinese EFL learners. The Linguistics Journal, 3(3), 148-166.

Hill, K., \& McNamara, T. (2012). Developing a comprehensive, empirically based research framework for classroom-based assessment. Language Testing, 29(3), 395-420.
Jin, L. (2011). Second language acquisition of spatial metaphors in English and Chinese writing: Insights from native and learner language corpora. The University of Arizona, Arizona.

Kalyuga, M., \& Kalyuga, S. (2008). Metaphor awareness in teaching vocabulary. The Language Learning Journal, 36(2), 249-257.

Khan, I. A. (2011). Learning difficulties in English: Diagnosis and pedagogy in Saudi Arabia. Educational Research, 2(7), 1248-1257.

Knight, C., Studdert-Kennedy, M., \& Hurford, J. (Eds.). (2000). The evolutionary emergence of language: social function and the origins of linguistic form. Cambridge University Press.

Lazar, G. (1996). Using figurative language to expand students' vocabulary. ELT journal, 50(1), 43-51.

Lakoff, G., \& Johnson, M. (1980). Metaphors we live by. Chicago: The University of Chicago Press.

Larsen-Freeman, D. (2000). Second language acquisition and applied linguistics. Annual Review of Applied Linguistics, 20, 165-181.

Li, T. F. (2009). Metaphor, image, and image schemas in second language pedagogy: The acquisition of metaphorical expressions, idioms, and proverbs by Chinese learners of English. Koln: Lambert Academic.

Littlemore, J. (2004). The misinterpretation of metaphors by international students at a British university: examples, implications, and possible remedies. Humanizing Language Learning, 6(3).

Littlemore, J., Krennmayr, T., Turner, J., \& Turner, S. (2014). An investigation into metaphor use at different levels of second language writing. Applied Linguistics, 35(2), 117-144.

Low, G. (2003). Validating metaphoric models in applied linguistics. Metaphor and Symbol, 18(4), 239-254.Mohammed, 2011.

Picken, J. (2007). Literature, metaphor and the foreign language learner. Basingstoke: Palgrave Macmillan.

Picken, J. D. (2005). Helping foreign language learners to make sense of literature with metaphor awareness-raising. Language Awareness, 14(2-3), 142-152.

Richards, J. C., \& Rodgers, T. S. (2001). Communicative language teaching. Approaches and methods in language teaching, 2 .

Skehan, P. (1998). A cognitive approach to language learning. Oxford University Press.

Sacristán, M. S. V. (2009). A translation approach to metaphor teaching in the LSP classroom: Sample exercises from a Business English syllabus. Ibérica, 17, 83-98.

Savignon, J. S. (1986). Teaching Second Language Reading for Academic Purposes. Addison-Wesley Publishing Company, Inc, USA.

Tuckner, N. R. (1986) The Integration of Media in the Curriculum Great Britain. Pergamon Press Ltd, UK.

Yasuda, S. (2010). Learning phrasal verbs through conceptual metaphors: A case of Japanese EFL learners. TESOL Quarterly, 44(2), 250-273. 